\title{
Baby Walker: Mother's Knowledge, Injury Prevention Behavior and Incidence of Injury among Toddler in Paseban District Jakarta
}

\author{
Velmi Revelin ${ }^{1}$, Sri Indiyah Supriyanti² \\ 1,2 Sekolah Tinggi IImu Kesehatan Sint Carolus \\ Salemba Raya 41 Jakarta Pusat 10440 \\ Email: velmi.revelin.vr@gmail.com
}

\begin{abstract}
Abstrak
Baby walker masih popular digunakan oleh beberapa keluarga, yang bertujuan agar anak dapat cepat berjalan, sementara penggunaan baby walker dapat menyebabkan kejadian cidera pada anak. Penelitian ini bertujuan mengetahui hubungan pengetahuan ibu dan perilaku pencegahan dengan kejadian cidera pada toddleryang menggunakan baby walker di Kelurahan Paseban. Desain penelitian descriptive corelatif dengan pendekatan cross sectional. Populasi penelitian berjumlah 83 responden dan pengambilan sampel menggunakan teknik total sampling. Data dianalisis menggunakan Chi-Square dengan tingkat kemaknaan a=0.05. Hasil penelitian menunjukkan kejadian cidera pada toddler yang menggunakan baby walker 47\%, ibu yang memiliki tingkat pengetahuan kurang $50.6 \%$ dan ibu yang memiliki perilaku pencegahan positif $55.4 \%$. Hasil analisis bivariate menunjukkan ada hubungan pengetahuan dengan kejadian cidera p-value 0.000, ada hubungan perilaku pencegahan dengan kejadian cidera pada baby walker p-value 0.000. Berdasarkan hasil penelitian tersebut, pentingnya peningkatan pengetahuan ibu tentang manfaat penggunaan dan pencegahan kejadian cidera pada anak yang menggunakan baby walker melalui penyuluhan. Ibu dengan pengetahuan yang baik diharapkan berperilaku positif dalam melakukan tindakan pencegahan cidera.
\end{abstract}

Kata kunci : Pengetahuan, Perilaku Pencegahan, Baby Walker

In many countries baby walkers are linked to more injuries than any other type of nursery equipments. Most parents have the impression that a baby walker will keep the baby safely entertained while they perform other tasks or will help the baby learn to walk. The study aimed to identify relationship between mother's knowledge and baby walker injury prevention on baby walker among toddler in Paseban district, Jakarta. A cross-sectional study based on a total sampling was employed with 83 participants aged 20-49 years old. The questionnaires composed of an individual characteristic questionnaire, knowledge of baby walker injury prevention questionnaire and baby walker injury prevention behavior. The study revealed the majority of participants were in age range of 30-39 years old (44.6\%). 43 participants were work and 50 of participants had a lower level of education. $53 \%$ of participants have a boys (53\%) and $50.6 \%$ of participants were less of knowledge. $44.6 \%$ of participant had a negative prevention behavior with $47 \%$ of participants reported their children had injuries. The Majority of children were fault from baby walker (66.6 \%). Knowledge of mothers had significant relationship with incidence of injury ( $p$ value 0.000 ) and baby walker injury prevention behavior had significant relationship with incidence of injury among toddler ( $p$ value 0.000). The knowledge of mothers should be improving. Therefore, knowledge about disadvantages of baby walker should be emphasized in primary health care program to promote avoid of using baby walker among toddler.

Keywords: Knowledge, Behavior Prevention, Baby Walkers 
Article info:

Article submitted on April 09, 2019

Articles revised on May 18, 2019

Articles received on June 20, 2019

DOI: http://dx.doi.org/10.21927/jnki.2019.7(2).74-78

\section{INTRODUCTION}

Parents have an important role in caring for their children. Busyness of parents especially mothers can have an impact on the lack of time of interaction and child care (8). Most parents choose to use baby walkers to replace them keeping the baby entertained while they are doing other tasks or helping babies learn to walk (7). Injury Database (IDB), nine countries in Europe in 2002 to 2007 showed that more than $90 \%$ of toddlers using baby walkers were head injuries, $31 \%$ of those affected by brain injuries, and $35 \%$ had skull injuries. Baby walkers are still widely used in Indonesia, or there are still many baby walker products sold in the market.

The results of interviews at several nursery shops in Jatinegara market, East Jakarta, obtained data that there are still 10 to 15 baby walkers sold in one month. Research conducted by Elizawarda (2010) in North Binjai shows that $85.45 \%$ of babies use baby walkers. Researchers also conducted interviews with 3 mothers who bought a baby walker found that they bought the device so the child could walk earlier, strengthen the baby's leg muscles, and the mother could put the child in the baby walker while the mother worked at home.

Baby walkers are still a matter of controversial because these tools have a positive and a negative effects for babies. People perceive that the using of baby walkers can help their children walk early, but in the real there is a high risk of injury to babies due to the use of baby walkers. Research from Barss et al (2016) at the United Arab Emirates obtained from 646 cases of injury to infants due to the use of baby walkers, 174 cases including more detail
118 babies treated in the emergency room, 42 hospitalization, 11 disabilities, and 3 deaths. The Australian Physiotherapy Association (APA) (2007) states that parents, caregivers and health workers have been arguing about the practice of placing babies who cannot walk on baby walkers. This association does not recommend the use of baby walkers because it can slow down the baby's gross motor skills (1).

Prevention of injury to infants due to the use of baby walkers is health education for parents about child development and development as early as possible (11). The education can change the parents perception about their children walk well according to age without using a baby walker. The parents should have a good knowledge about baby walker injury prevention by using baby walker among their children. Then, if the parents have a good knowledge so the injury will be preventing. Therefore, this study aims to identify relationship between mother's knowledge and baby walker injury prevention on baby walker among toddler in Paseban district, Jakarta.

\section{MATERIALS AND METHODS}

A cross-sectional study was conducted in Paseban District, Jakarta. The objective of this study was to identify relationship between mother's knowledge and baby walker injury preventionon baby walker among toddler. The total sampling was employed with eighty three participants.

Questionnaires that were employed in this study were composed of an individual characteristic questionnaire, knowledge of baby walker injury prevention questionnaire with 
12 items, and baby walker injury prevention on baby walker questionnaire with 13 items. Questionnaires were reliable to use, the knowledge questionnaire obtained Cronbach's alpha 0.88 and baby walker injury prevention obtained Cronbach's alpha 0.94.

The study has got permission from Sint Carolus School of Health Science and Head of Paseban district. All participants were signed informed consent.

\section{RESULTS AND DISCUSSION}

Table 1 describes the majority of participants were in age range of 30-39 years old (44.6\%). Forty three participants were work and 50 of

Table 1.Characteristics of participants $(n=83)$

\begin{tabular}{lcc}
\hline \multicolumn{1}{c}{ Individual characteristics } & Frequancy & $\%$ \\
\hline Age (years) & 30 & 36.1 \\
$20-29$ & 37 & 44.6 \\
$30-39$ & 16 & 19.3 \\
$40-49$ & & \\
Education Level & 50 & 60.2 \\
Lower & 33 & 39.8 \\
Higher & & \\
Employments status & 43 & 51.8 \\
Employed & 40 & 48.2 \\
Unemployed & & \\
Gender of Children & 39 & 47.0 \\
Female & 44 & 53.0 \\
Male & & \\
Knowledge & 41 & 49.4 \\
Good & 42 & 50.6 \\
Less & & \\
Baby walker injury prevention & 46 & 55.4 \\
Positive & 37 & 44.6 \\
Negative & & \\
Incidence of Injury & & \\
Frequently & & \\
Never & & \\
Injury type & & \\
Fault & & \\
Stumble & & \\
Stricken by stuff & & \\
\hline
\end{tabular}

Table 2.Relationship between level of knowledge and incidence of injury among toddler $(n=83)$

\begin{tabular}{lcccccccc}
\hline \multirow{2}{*}{$\begin{array}{c}\text { Knowledge } \\
\text { Level }\end{array}$} & \multicolumn{3}{c}{ Incidence of injury } & \multirow{2}{*}{ Total } & \\
\cline { 2 - 6 } & \multicolumn{2}{c}{ Frequently } & \multicolumn{2}{c}{ Never } & & & p-value \\
& $\mathrm{n}$ & $\%$ & $\mathrm{n}$ & $\%$ & $\mathrm{n}$ & $\%$ & \\
\hline Good & 11 & 26.8 & 30 & 73.2 & 41 & 100 & 0.000 \\
Less & 28 & 66.7 & 14 & 33.3 & 42 & 100 & \\
\hline
\end{tabular}

participants had a lower level of education. Forty four participants have a boys (53\%) and $50.6 \%$ of participants were less of knowledge. According to baby walker injury prevention, $44.6 \%$ of participant had a negative prevention behavior with $47 \%$ of participants reported their children had injuries. The Majority of children were fault from baby walker (66.6 \%).

Table 2, the results revealed that $73.2 \%$ of participants who has a good knowledge will be never had injury incidence among toddler who using baby walker and knowledge of mothers had significant relationship with incidence of injury ( $p$ value 0.000 ). This finding consistent with Notoatmodjo (2010) mentioned about knowledge level of a person was influenced by several factors such as education, age and work. This is also in line with the findings of research that found the majority of participants had a good knowledge related to education level.

The situation showed the mother's who had a low knowledge will be increasing incidence of injury. Therefore, the mother's knowledge should be improving to reduce incidence of injury. If, mother has a good knowledge, they will aware to protect their children. This sudy accordance with study by Dewi and Indarwati (2011) found that parent's knowledge has relationship with incidence of injury on baby walker among toddler.

Table 3.Relationship between baby walker injury prevention behavior and incidence of injury

\begin{tabular}{ccccccccc}
\hline Baby & \multicolumn{3}{l}{ Incidence of injury } & & & \\
\cline { 2 - 6 } $\begin{array}{c}\text { walker } \\
\text { injury } \\
\text { prevention } \\
\text { behavior }\end{array}$ & Frequently & Never & & Total & p-value \\
\hline Positive & 13 & 28.3 & 33 & 71.7 & 46 & 100 & 0.000 \\
Negative & 26 & 70.3 & 11 & 29.7 & 37 & 100 & \\
\hline
\end{tabular}

Table 3 showed the significant relationship between baby walker injury prevention behavior and incidence of injury among toddler ( $p$ value 0.000 ). That's mean mother who had positive injury presentations behavior will able to reduce 
incidence of injury among their children. However, in this study still found 37 participants has negative baby walker injury prevention behavior. Several studies found some rationales of parent who still using baby walker. Most parents have the impression that a baby walker will keep the baby safely entertained while they perform other tasks or will help the baby learn to walk (7).

Previous study by Badhian, Adhiani and Yaghini (2017) found that the uses of baby walker were increasing dramatically. The most type of baby walker was entertained with toys and music. Therefore, the parents assume the children will happy with the toys. However, that study also found, $50-70 \%$ of children (4-12 month old) who using baby walker were delayed developments.

This finding also in line with studies by Widyaningsih and Widaryati (2014) and Akenet et al (2007) that found Baby walker injury prevention behavior has relationship with injury of incidence on baby walker. Therefore, the mothers should be aware with baby walker injury prevention and avoid usingbaby walker for their children. The mothers also should able to perform their roles as mother to protect and stimulate their children not only by using baby walker.

\section{CONCLUSIONS AND RECOMMENDATIONS}

This study reached that $47 \%$ toddler were fault by using baby walker and $50.6 \%$ of participants had a less of knowledge. However, $55.4 \%$ of participants reported had a positive of baby walker injury prevention behavior. There were significant relationship between level of knowledge and incidence of injury ( $p$ value 0.00 ).

Based on findings, the knowledge of mothers should be improving. Therefore, knowledge about disadvantages of baby walker should be emphasized in primary health care program to promote avoid of using baby walker among toddler. Moreover, this study should be a reference for improving nursing knowledge and health volunteer awareness in community.

\section{REFERENCES}

1. Aken, CV, Verhoeven, M., Aken, GV, \&Dekovic, M. (2007). Externalizing Behaviors And Minor Unintentional Injuries In Toddlers. Journal of Pediatric Psychology(32 (2)), 230244. doi: 10.1093 / 118

2. Atak, N., Karaoglu, L., Korkmaz, Y., \&Usubütün, S. (2010). A Household Survey: Unintentional Injury Frequency And Related Factors Among Children Under Five Years In Malatya. Turkey: The Turkish Journal of Pediatrics. doi: 52: 285-293

3. Australian Physiotherapy Association. (2007). Position Statement: Baby Walkers. Retrieved April 10, 2016, from the Australian Physiotherapy Association: http://pediatrics. aappublications.org

4. BADIHIAN S, ADIHIAN N, YAGHINIO. (2017). The Effect of Baby Walker on Child Development: A Systematic Review. Iran J Child Neurol, 2017 Autumn Vol.11 No.4. http://journals.sbmu.ac.ir/ijcn/article/ view/15509/1-6

5. Barss, et al. (2016). Baby walker injury, disability, and death in a high-income middle eastern country, as reported by siblings. Injury Epidemiology , 3-17.

6. Dewi, R., \&Indarwati. (2011, August 2). Relationship Between Knowledge and Attitudes of Parents About Dangers Injury and Baby walker injury prevention Method In Childhood Toddler in Sub BlumbangTawangmangu District of Karanganyar. Journal Gaster,VIII,750-764. Retrieved June 16, 2016, from www.jurnal. stikes-aisyiyah.ac.id

7. Elizawarda. (2011). Relationships Use Baby Walker With Baby Free Walk In Clove Turi Sub District of North Binjai. Scientific Journal PANNMED, VI,73-78. Retrieved May 24, 2016, from http://pannmed.poltekkes-medan. ac.id 
8. Kusbiatoro, D. (2014, June). Practice Childhood Baby walker injury prevention In Toddler Seen From Knowledge and Attitudes of Parents About Dangers Injury In the village KembangbahuKembangbahu District of Lamongan. Solar Journal,II,32-40. Retrieved June 16, 2016, from http://stikesmuhla.ac.id

9. Notoatmodjo, S. (2010). Health and Education Research Methodology. Jakarta: Rineka Reserved.

10. Notoatmodjo, S. (2012). Health Behavioral Science. Jakarta: Rineka Reserved.

11. Shiva, F. G. (2015). The use of baby walkers in Iranian infants. Singapore Medicine Jurnal, 645.
12. The European Child Safety Alliance (ECSA). (2010). European Child Safety Alliance and Anec joint position statement: Baby walkers. Retrieved April 10, 2016, from the European Association For Baby walker injury prevention and Safety Promotion: www. childsafetyeurope.org

13. Widyaningsih, A., \&Widaryati. (2014). Ms. Behavior Relationships In Genesis Baby walker injury prevention Injury With Toddler in Yogyakarta attack. MedicalJournal.Retrieved June 12, 2016, from https://skripsistikes. wordpress.com 